\section{A CRITICISM OF}

\section{THE MEMORANDUM ON MALARIA.}

\section{To the Editor of THE LANOET.}

Sir,-I must protest against the pernicious and dangerous advice given by Dr. Gordon Ward in his criticism of the Memorandum on Malaria in your issue of July 19th. He says :-

* The most important principle in the treatment of malaria in pensioners is the improvement of the natural resistance of the body with the aid of as little quinine as possible."

It is just such treatment that is filling the wards in our hospitals with pensioners and demobilised men. They all come in with the same story. Since they left the Army they have had recurrent attacks of fever, been treated by civil practitioners with totally inadequate doses of quinine, which have had no effect on their malaria, and finally have to come into hospital. There they are put on 10-gr. doses of quinine sulphate in solution, three times a day, and they very rarely have more that one rigor after the treatment has begun. It is a great relief to the men to find they are rid of their fever in 48 hours, after recurrent attacks ; in one case for five weeks on minimum doses of quinine. It may now be regarded as established beyond a doubt that the optimum dose of quinine during the attack is that stated in the Memorandum-viz., $10 \mathrm{gr}$. of sulphate or hydrochloride in solution three times a day; whilst the experience at concentration eentres has proved that $10 \mathrm{gr}$. a day is a valuable anti-relapse precaution. If this be carried out regularly over a prolonged period, say, three months, and relapses prevented, the natural resistance of the body will assert itself and justify Osler's dictum, that the proper treatment of malaria is "quinine and time, both in divided doses."

The danger we have to fight against is the fear of the civil practitioner to give adequate duses for a sufficiently long period, and we are not helped by such advice as Dr. Ward gives. Dr. Ward's picture of the man with chronic tachycardia and effort syndrome is in most cases the result of inadequate doses of quinine for a short period, allowing frequent relapses and general deterioration of health. If Dr. Ward will.re-read the Memorandum carefully he will find that the intramuscular method of administration is recommended only when vomiting is so persistent that quinine cannot be given by the mouth, or in pernicious attacks, when no time must be lost. It is not advocated in simple attacks without complications.

Twenty months in the malaria section of a military hospital in England have only confirmed what 20 years' experience in the tropics had already taught me, that the intramuscular giving of quinine is a most valuable method in urgent cases, and that by using quinine bi-hydrochloride, being careful about sterilising the solution, and all the apparatus, and making the injection actually into the muscle and not subcutaneously, the risk of causing abscess is small, whilst a very elementary knowledge of anatumy will enable one not to inject in the close proximity of an important nerve trunk. In about 2000 cases I have had through my hands in this country I have seen only one partially paralysed arm as the result of an injection, and in that case the needle had been inserted directly over the musculo-spiral nerve. Pernicious attacks in this country fortunately are rare, but in such cases the intramuscular route is pre-eminently the safest for the civil practitioner to follow.

$$
\text { I am, Sir, yours faithfully, }
$$

T. H. JAMIESON, M.D., M.R.C.P. Edin.,

London, July 31st, 1919.

$$
\text { D.T.M.H., D.P.H. }
$$

\section{DUPLICATION IN HUMAN SPERMATOZOA.}

To the Editor of THE LANCET.

Sir,-If Mr. S. R. Tattersall, who communicated to The LANCET of August 2nd on the above subject, would look up Broman's "Normale und Abnorme Entwicklung des Measchen," p. 18 et seq., he will find the conditions he has described as well as excellent photographs of the specimens. He will further find an interesting discussion of the whole question of abnormal spermatozoa, by one who has done much work on the subject, but whose magnificent book seems to be little known.

I am, Sir, yours faithfully,

EDWARD FAWCETT,

August 2nd, 1919. Professor of Anatomy, University of Bristol.
THE RESULTS OF COMPLETE COLECTOMY. To the Editor of THE LANOWT.

SIR,-Major James Taylor is quite correct in stating, in your isşue of August 2 nd, that there is a very general belief that many patients do not recover from the operation (of complete colectomy), and that those who do are no longer capable of leading an active life. This general impression is not likely to be changed in any way by a perusal of Major Taylor's paper. His small series of cases is of undoubted interest, but it is to be regretted that he does not give any information of the after-progress of Cases 1 and 2 and a full description of the "diseased condition of the rectum" held responsible for the imperfect recovery of Case 3 . The operation of complete colectomy for intestinal stasis will remain under a cloud so long as those surgeons who perform it are content to support their views by the publication of their cases in this imperfect manner.

Leeds, August 2nd, 1919.

I. am, Sir, yours faithfully,

\section{SHELL SHOCK IN FISHES.}

To the Editor of ThE LANCET.

SrR,-Dr. Alfred Carver narrates in your columns last week certain experiments on fishes; these were made only on perches. Dc. Carver will be interested to hear that Dr. A. G. Mayer ${ }^{1}$ found that when a halt stick of dynamite was exploded within $3 \mathrm{ft}$. of a small shark (Carver's zone A with a vengeance) no apparent injury was produced; the same thing applied in a lesser degree to such teleosts as lack swim-bladders. When swim-bladder fishes were killed by the explosion their swim-bladder burst, the tissues were crushed, and the vertebral column was often broken. Mayer attributes the injurious effects of explosives in fishes, when present, to mechanical laceration of tissues, and especially the crushing inward of air-filled cavities. A full abstract of Mayer's paper appears over mp signature in the Rexievo of Neurology and Psychiatry, 1917, xv., p. 335.

I am, Sir, yours faithfully,

London, N.W., August 1st, 1919. LEONARD J. KLDD.

\section{HOME HOSPITAL ESTABLISHMENTS AND THE WAR MEDALS. \\ To the Editor of THE LANOET.}

SIR, - I wish to call attention to the gross unfairness of laying down ageographical qualification for the 1914-15. Star, General Service, and Victory Medals, at all events as regards the medical establishments. Elderly medical men in the R.A.M.C., whether Reserve, Special Reserve, or Territurial, were called up at the ontbreak of the war in August, 1914. Often this entailed the abandenment of our private practices, our means of livelihood, and serious financial loss. We hare been in charge of, or performing important services in, large general bospitals and their auxiliaries, or in the military hospitals and training camps; and we have been kept in this country because we could not be replaced. We have been overwhelmed with work which has been absolutely essential, yet we have not been considered to be entitled to the medals issued to commemorate this, the greatest of all wars, because, forsooth, we have not crossed the Channel!

This decision is contrary to precedent. It has always previously been recognised that the medical establishment had a special claim to medals issued to commemorate:a campaign in view of their special work of dealing with the wounded. The hospitals in this country have equally with those in France been associated with the fighting foroes. They have taken wounded practically direct from the battlefields, Americans, Belgians, Chinese, French, Serbians, besides the British and Dominion troops; yet, having performed these services to our Allies, we alone of all the Allied forces are not to have the Allies Medal! It is-sought to justify this discrimination by excluding this country from the list of "war areas." But we who, by the exigencies of the service, were retained here, have been declared to be serving "on Active Serrice" and have drawn "Field Allowances." Hitherto the necessary corollary to such conditions has been the issue of the medal granted for the campaign.

What makes this discrimination more remarkable is that it does not apply to Dominion troops. They receive not

1 Proc. National Acad. Sciences of U.S.A., 1917, iii., p. 597. 